\title{
VEGETATION SUCCESSION ALONG NEW ROADS AT SOQOTRA ISLAND (YEMEN): EFFECTS OF INVASIVE PLANT SPECIES AND UTILIZATION OF SELECTED NATIVE PLANT RESISTENCE AGAINST DISTURBANCE
}

\author{
PETR MADĚrA ${ }^{1}$, PAVEL KOVÁ ${ }^{2}$, JAROSLAV VOJTA ${ }^{2}$, DANIEL VOLAŘÍK ${ }^{1}$, \\ LUBOŠ ÚRADNÍČEK ${ }^{1}$, ALENA SALAŠOVÁ ${ }^{3}$, JAROSLAV KOBLÍŽEK ${ }^{1}$ \& PETR JELÍNEK ${ }^{1}$ \\ ${ }^{1}$ Mendel University in Brno, Faculty of Forestry and Wood Technology, Department of \\ the Forest Botany, Dendrology and Geobiocoenology, Zemédělská 1/1665, 61300 Brno \\ ${ }^{2}$ Charles University in Prague, Faculty of Science, Department of Botany, Benátská 2, \\ 12801 Prague \\ ${ }^{3}$ Mendel University in Brno, Faculty of Horticulture, Department of Landscape Planning, \\ Valtická 337, 69144 Lednice
}

Received: $13^{\text {th }}$ November 2013, Accepted: $17^{\text {th }}$ December 2013

\begin{abstract}
The paved (tarmac) roads had been constructed on Soqotra island over the last 15 years. The vegetation along the roads was disturbed and the erosion started immediately after the disturbance caused by the road construction. Our assumption is that biotechnical measurements should prevent the problems caused by erosion and improve stabilization of road edges. The knowledge of plant species which are able to grow in unfavourable conditions along the roads is important for correct selection of plants used for outplanting. The vegetation succession was observed using phytosociological relevés as a tool of recording and mapping assambblages of plants species along the roads as new linear structures in the landscape. Data from phytosociological relevés were analysed and the succession was characterised in different altitudes. The results can help us to select group of plants (especially shrubs and trees), which are suitable to be used as stabilizing green mantle in various site conditions and for different purposes (anti-erosional, ornamental, protection against noise or dust, etc.).
\end{abstract}

Key words: Road construction; altitudinal gradient; mountain areas; plant invasion; environmental impact; vegetation management; tropics; islands; Soqotra;

\section{INTRODUCTION}

The environmental impacts of newly built network of roads in natural areas in the world became frequently dicussed subject in scientific circles associated with wildlife management (e.g., Dogra et al., 2010). Soqotra Island integrates the problem due to the fact it falls in three areas of interest: (1) tropics (e.g., Goosem \& Turton, 2006; Youg \& León, 2007), (2) mountains (e.g., Arévalo et al., 2005; Pauchard et al., 2009; Kosaka, 2010), and (3) islands (e.g., Daehler, 2005; Arteaga et al., 2009). 
Soqotra island belongs to the isolated lands with the highest level of endemism of vascular plants (Cheung \& Devantier, 2006) - $37 \%$ of almost 900 species (Miller \& Morris, 2004; Brown \& Mies, 2012). In 2003 the archipelago was declared a reserve under UNESCO's Man and the Biosphere Programme, followed by its listing as a World Heritage Site (Scholte et al., 2011) in 2008, especially for its biodiversity significance. Soqotra was relatively untouched by tourism until the end of the last millenium but tourist numbers have doubled every 18 months since 2003, more then 4 thousand tourist visited Soqotra island in 2008 (Scholte et al., 2011).

The European Union mission in Yemen commissioned a master plan for the development of Soqotra. The consultants produced investment plans for the main economic sectors including roads. Although approved by the Ministry of Planning the master plan has, however, never been implemented (Sholte et al., 2011). Since the end of the nineties of last century the Yemeni Government started to invest to tarmac road construction on Soqotra. The road system development, on which Yemen has spent ca. USD 70 million, the highest per capita road expenditure in the country, was evaluated as an inappropriate (Scholte et al., 2011). The dimension of roads was oversized (the width was $8 \mathrm{~m}$ ) and the road construction was not accompanied by any environmental measures (Scholte, 2007). More than $1 \%$ of island surface had been affected by the development.

Road construction caused direct disturbance of vegetation along the roads and the erosion started consequently. The door for invasion of alien species was open (Senan et al., 2012).

The aim of our work is to describe the vegetation succession along disturbed bands of roads and to determine suitable (woody) plant species for potential biotechnical measures in various site conditions.

\section{Natural history of the Soqotran archipelago}

Four islands of the Soqotran archipelago (Soqotra, Abd al Kuri, Samha and Darsa) are separated from one another by shallow sea waters, however, the mainland of Africa by narrow trench deep several hundreds meters. Distance from Somalia (Africa, west) is approx. $80 \mathrm{~km}$ and from Arabia (north) approx. $380 \mathrm{~km}$. Basic physiographic components of major island (Soqotra) are (1) the coastal plains, (2) the limestone plateau and (3) the igneous Haggeher mountains. The most part of this largest island of the archipelago is covered by Cretaceous and Tertiary limestones. On the coastal plateau and inland depressions Quaternary and recent deposits of Pleistocene and Holocene age overlay the older rocks. Soqotra island has its geographical position in the tropical arid climatological zone (Scholte \& De Geest, 2010) and the plant communities correspond with its delimitation (De Sanctis et al., 2013; Kürschner et al., 2006; Brown \& Mies, 2012; Miller $\&$ Morris, 2004). Climate is influenced by SW monsoon (summer, June - September) bringing hot and dry winds from Africa and NE monsoon (winter, November - January) with predominant NE winds bringing most rain falls (Culek et al., 2006). Tropical storms and cyclones occur in the area every few years. Environmental features and course of yearly regimes suggest rather dry tropics with different extremes during the elevational gradient from coastal plateau up to mountain range (the highest peak: Jebel Skand - over $1535 \mathrm{~m})$.

Soqotra belongs to the Eritreo-Arabian subregion from the flora point of view (it includes S Arabia, Somalia. Ethiopia and large parts of Kenya and Tanzania; Takhtajan 1986). The island flora exhibits one subendemic family (Dirachmaceae), 15 endemic genera (of the total 430 belonging to 114 families) and 307 endemic species (of the total 825; Miller \& Morris, 2004). Plant species diversity and endemism of the Soqotra archipelago is enormous and requires extremely high degree of protection as a part of the global 
conservation effort. The relationship of the flora is confirmed to Arabia, Africa and Macaronesia, Madagascar and the New World. This area is known as arid territory with fluctuations in rainfall over the past 150000 years. The surface landforms are old and geologically they belong to the ancient southern supercontinent Gondwana. Among theories on the origin of endemic species surviving on the archipelago, the last one declares that distribution of some genera in Arabia, India, S Asia, Madagascar and Soqotra may be explained by their origin in Soqotra (which is placed in a central position within Gondwana) and continual dispersal with the continental fragments into the present disjunct areas (Klackenberg, 1985). Molecular data (Magallón et al., 1999) show that long-term dispersal of some taxonomic groups supported significantly their present distribution. To explain dissimilarity in rich/poor differentiation of genera present in Soqotra is not easy because of difficult setting of barriers to gene flow between (sub)populations. However, speciation processes and selection pressures are continuously acting and human impacts of the modern era (artificial disturbance through building infrastructure, erosion and pollution, removal of some components of vegetation and decreasing their competition, introduction of invasive species as new competitors, etc.) surely influence the next development of ecosystems.

\section{MATERIAL AND METHODS}

\section{Study area}

The disturbed vegetation was recorded along the tarmac road from the northeast part (near to Arher spring) to the central south part (Noged, Stero) of the island (Fig. 1). The altitude of particular research plots ranged from the sea level to the 986 m.a.s.l. (Fig. 2). The undisturbed vegetation was recorded on shorter route, starting point was by the roads junction from Hadibo to Qualancia and to Dixam. The site conditions were described by vegetation zones (De Sanctis et al., 2013; Habrová, 2004). The map of vegetation zone published by Buček et al. (2004) was used for placing the plots to vegetation zones.

\section{Fig. 1: The route of vegetation surveys along the roads}

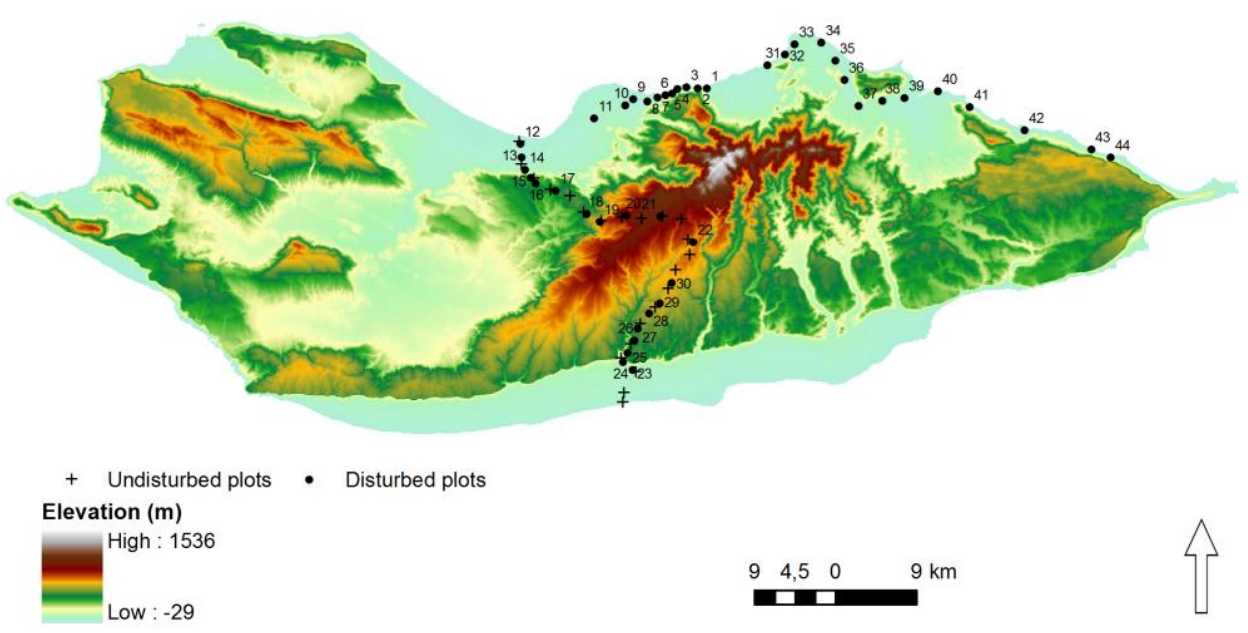


Fig. 2: Cross-section of the altitudinal vegetation zones along road line with distribution of recorded plots

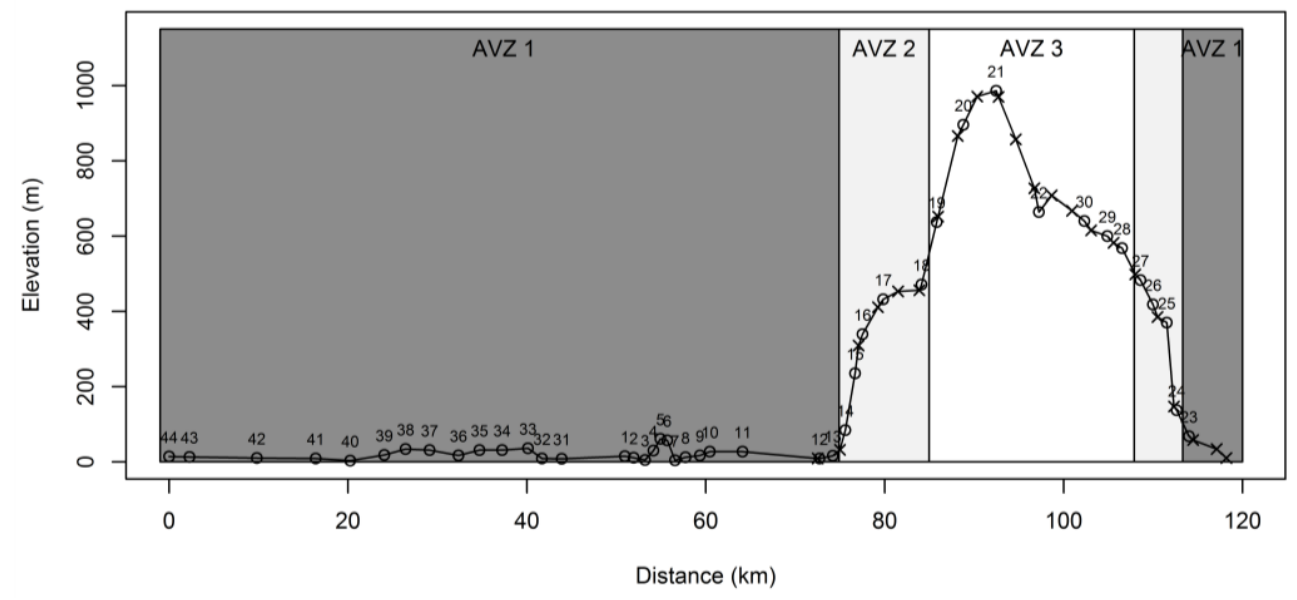

\section{Data collection}

Sampling design consisted of recording phytosociological relevés taken along two transects parallel with the road that runs across the altitudinal gradient over the Haggeher Mts. (south - north) in February 2011. Sampling area was 20 × $5 \mathrm{~m}$ and the double plots were situated on both sides of the road. The spacing of the plots was done randomly, each 5 minutes of drive a plot was placed. For comparison of disturbed and undisturbed vegetation, the relevés were also located in $50 \mathrm{~m}$ perpendicular distance from the road (size 10 x $10 \mathrm{~m}$; May 2010). The first gradient represents the initial stage of vegetation succession, the second one records mature stands. In total, 44 double plots of disturbed and 22 plots of undisturbed vegetation were surveyed. Seven-grade scale of abundance was used for phytosociological relevés (Braun-Blanquet, 1928):

- 1 plant individual and/or nearly zero abundance

+ rare plant, however, maybe several individuals with very small abundance

1 less than $5 \%$

$26-25 \%$

$326-50 \%$

$451-75 \%$

$576-100 \%$

The coordinates of plots were based on GPS.

\section{Data analysis/statistics}

The relevés of disturbed vegetation served to describe vegetation succession after road construction. Only comparable parts of route were used to measure disturbed and undisturbed vegetation segments.

Detrended correspondence analysis (DCA) in CANOCO for Windows (version 4.5, Microcomputer power, Ithaca, NY, US; ter Braak \& Šmilauer, 2002) was used to find the main gradients in the dataset. We used 7 zones as co-variates to filter out the possible effect of altitude and to compare only relevant samples. Percentages of species cover were square root transformed to reduce the effect of species with high cover. The down-weighting of rare species then followed. The sample scores of sites on the first ordination axis were 
tested for correlation with disturbance using standard ANOVA (Crawley, 2007) in R (version 3.0.1, The R Foundation for Statistical Computing).

We monitored the effect of altitudinal gradient and its interaction with disturbance using Canonical Correspondence Analysis (CCA) in CANOCO for Windows. The species covers and rare species were treated in the same way as in DCA. Monte Carlo permutation tests were used to obtain significance values (we used 499 permutations under reduced model). All other settings were default.

To test the differences between sites in number of species and proportions of life forms we used nonparametric two sample Wilcoxon test (Hollander \& Wolfe, 1999).

\section{RESULTS}

\section{CHARACTERISTICS OF SUCCESSION}

\section{Species composition}

In total, 85 species were recorded in plots along the roads. Tab. 1 shows 21 species with frequency higher than $10 \%$, they are abundant plants. It means, approximately $75 \%$ of the all species were present with frequency less than $10 \%$, they are scattered and rare plants. Only two species among abundant plants reached mean cover higher than $10 \%$ and four species exhibited the cover values higher than $1 \%$. This is the reason, why disturbed vegetation along the roads seems to be monotonous, with dominance of Tephrosia apollinea, Pulicaria stephanocarpa, Senna holosericea and invasive alien Argemone mexicana.

Table 1: Species with frequency higher than $10 \%$

\begin{tabular}{|c|c|c|}
\hline species & frequency & mean cover \\
\hline Tephrosia apollinea & 79.5 & 19.1 \\
\hline Senna holosericea & 48.9 & 1.8 \\
\hline Launaea rhynchocarpa & 37.5 & 0.3 \\
\hline Corchorus depressus & 34.1 & 0.4 \\
\hline Euphorbia kishenensis & 33.0 & 0.3 \\
\hline Croton socotranus & 31.8 & 0.5 \\
\hline Oldenlandia pulvinata & 30.7 & 0.3 \\
\hline Cleome brachycarpa & 29.5 & 0.4 \\
\hline Indigofera nephrocarpa & 29.5 & 0.2 \\
\hline Jatropha unicostata & 28.4 & 0.2 \\
\hline Helichrysum gracilipes & 26.1 & 0.6 \\
\hline Withania riebeckii & 21.6 & 1.2 \\
\hline Argemone mexicana & 20.5 & 1.5 \\
\hline Pulicaria stephanocarpa & 17.0 & 10.2 \\
\hline Eragrostis minor & 14.8 & 0.7 \\
\hline Indigofera pseudointricata & 12.5 & 0.3 \\
\hline Aerva lanata & 11.4 & 0.2 \\
\hline Indigofera articulata & 11.4 & 0.8 \\
\hline Lycium sokotranum & 11.4 & 0.2 \\
\hline Oxalis corniculata & 11.4 & 0.5 \\
\hline Haya obovata & 10.2 & 0.3 \\
\hline
\end{tabular}


Other relatively abundant species are low, often decumbent herbaceous species or subshrubs, for example Launea rhynchocarpa, Corchorus depressus, Euphorbia kishenensis, Oldenlandia pulvinata, Cleome brachycarpa or Helichrysum gracilipes. The only abundant woody plants (higher shrubs) are Croton socotranus, Jatropha unicostata and Lycium sokotranum, but with low mean cover, i. e. on the plots with only a few specimens.

\section{Differences between disturbed and undisturbed vegetation}

Disturbance associated with the road construction has strong effect on vegetation. It is the most important gradient revealed by DCA (Fig. 3). There are almost no overlaps in species assemblages and we found only small number of species common for both disturbed and undisturbed sites (e.g. Cissus subaphylla, Trichocalyx orbiculatus, Corchorus erodioides).

Fig. 3: DCA analysis of the whole dataset shows very distinct species assemblages in disturbed (red discs) and undisturbed (green triangles) sites. The difference of sample scores on the first axis between disturbed and undisturbed sites is highly significant (pvalue $<0.0001, \mathrm{~F}=227.3)$.

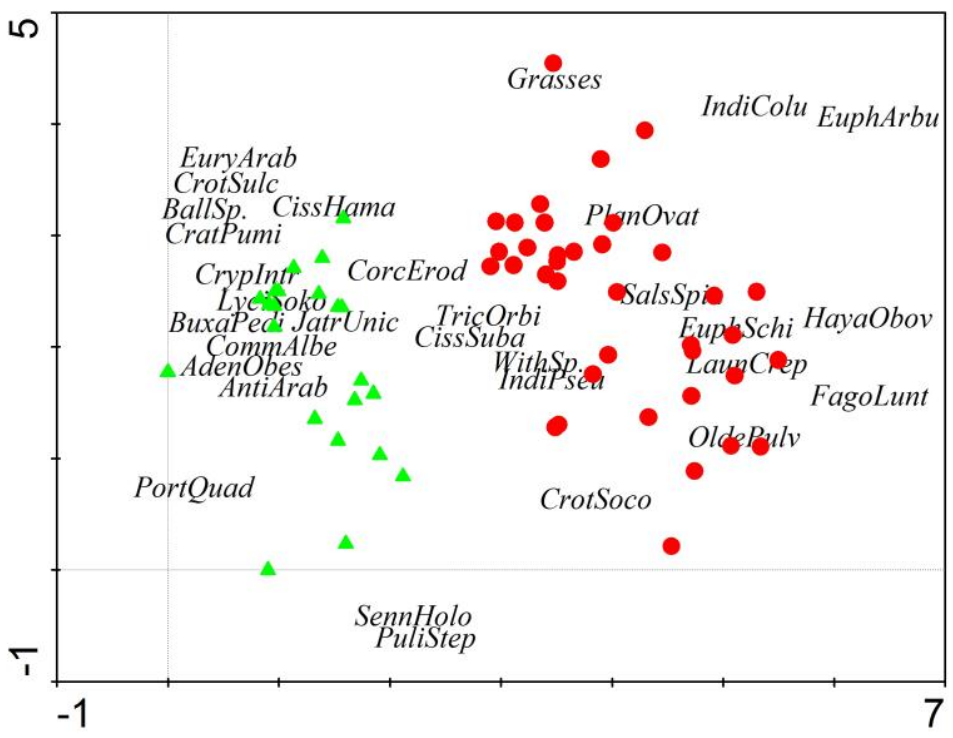

\section{Comparison of the life form occurrence}

Herbaceous species represent the most prevalent life form in vegetational stage of succession along the roads, shrubs and other life forms are present less frequently (Fig.4). Differences between disturbed and undisturbed vegetation are particularly shown in higher proportion of trees and shrubs in undisturbed vegetation and presence of ferns which are completely missing along the roads. Grasses are more diverse in disturbed vegetation (Fig. 5). 
Fig. 4: Distribution of different life forms among sites. 61 most common species species are projected in the same ordination space as in the Fig. 3

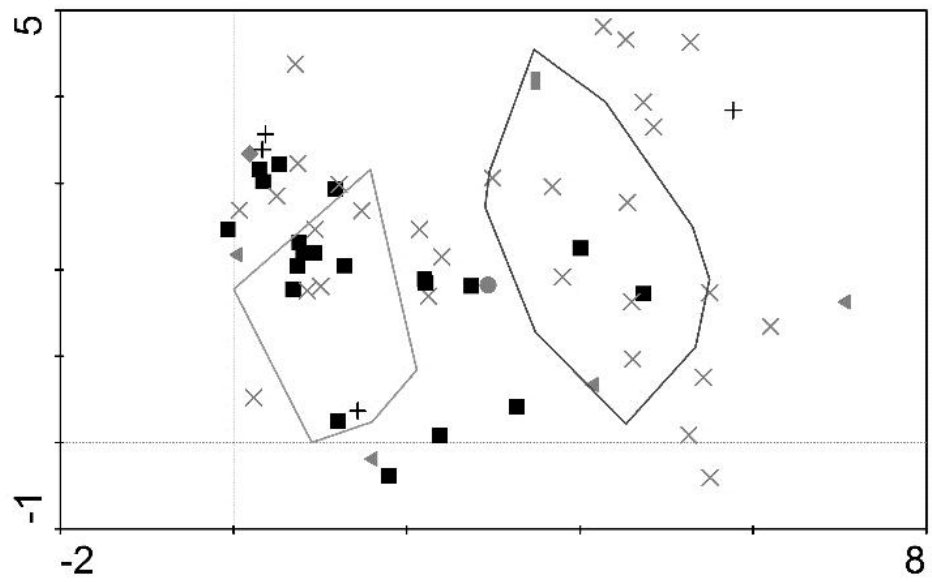

Life form of species

Shrubs $X$ Herbs $\quad$ Subshrubs 4 Other
Ferns + Trees $\quad$ grasses

Envelopes for samples

- Disturbed - Undisturbed

Fig. 5: Occurence of life form in undisturbed (blue columns) and disturbed (purple columns) vegetation

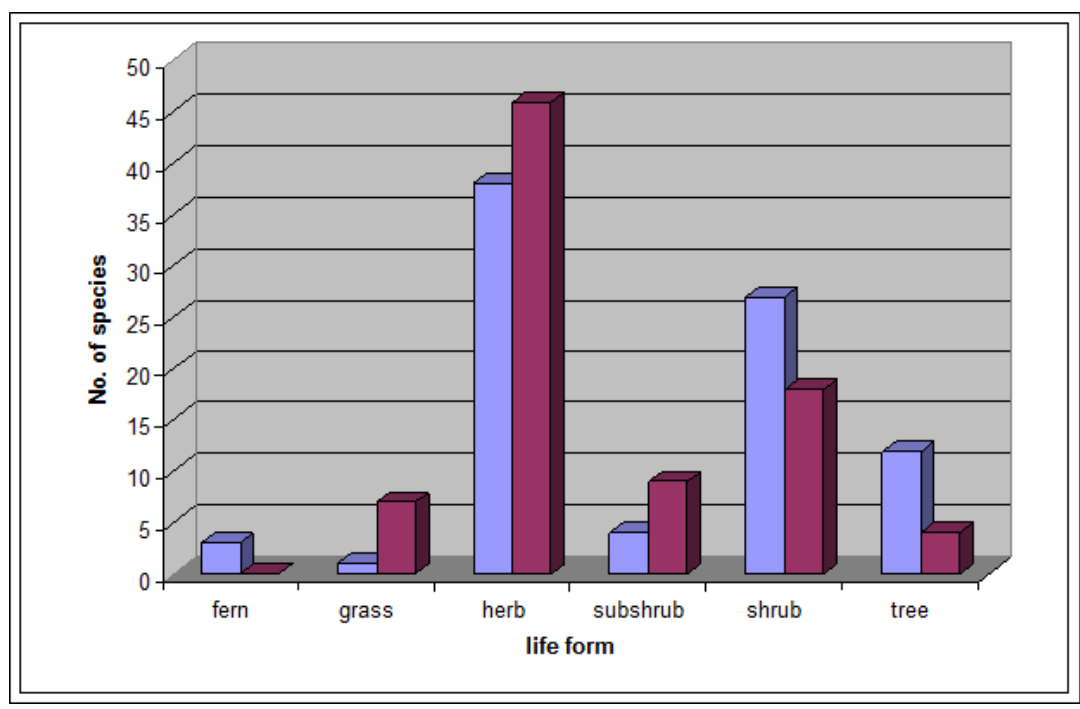




\section{Proportion of endemic and alien species}

The number of endemic species is higher in undisturbed vegetation as is shown in Fig.6, on the contrary there are more adventive (alien) species found in disturbed vegetation.

Fig. 6: Occurence of endemic, nonendemic and alien (adventive) species in undisturbed (blue columns) and disturbed (purple columns) vegetation

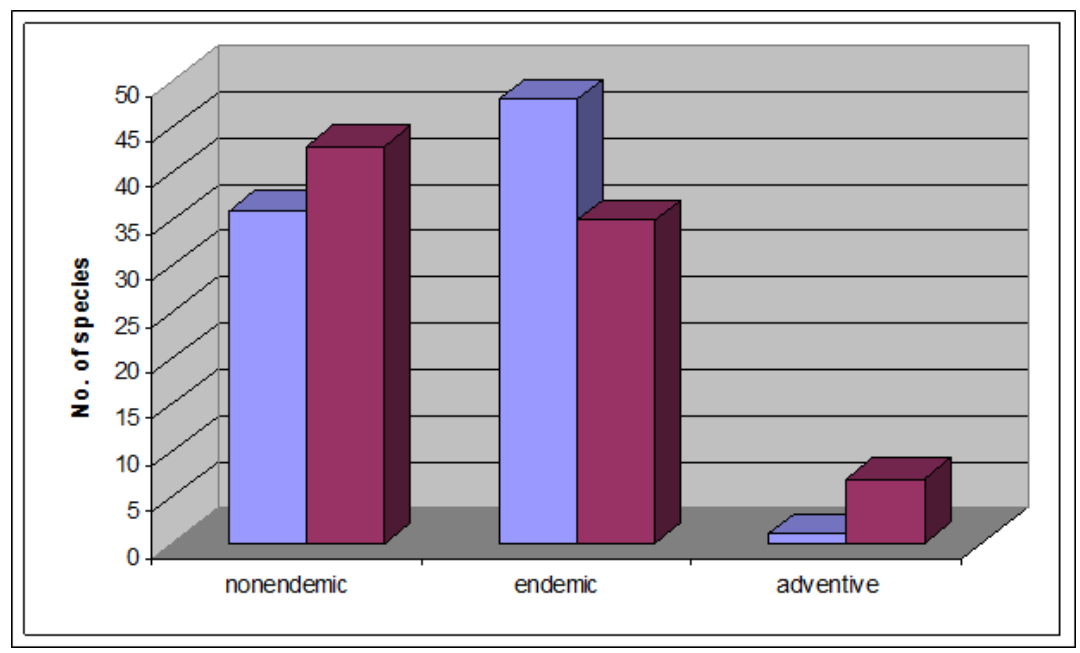

\section{Differencies among altitudinal vegetation zones}

Changes within the altitudinal transect during travelling from the coast to the inland territory represent changes in vegetation (Fig. 7). For example, grasses and some indicators of strong human impact and grazing pressure (e.g., Plantago ovata, Indigofera pseudointricata) are gradually decreasing in their frequency with raising altitude. It is obvious that altitude modifies the effect of disturbance. This phenomenon is enhanced in higher altitudes while in the lower altitudes the diferences between plots are less significant (Fig 7). It was confirmed by CCA, where the interaction between altitude and disturbance was significant ( $\mathrm{p}$-value $=0.002$, variance explained by the model was $6.7 \%$ ).

There are significant differences in vegetation and environmental parameters between mountains compared with lowland areas (McDougall et al., 2011). This fact is apparent also in segments of our Soqotran altitudinal gradient of vegetational records which is the reason to assess only the data from the Haggeher Mts., not from the lowland region where changing proportion of native and alien plant species could be caused by other factors than in higher elevations (e.g., Arévalo et al., 2005). The species recorded in the mountains were divided into the groups according to their presence in altitudinal vegetation zones - they are shown in Tab. 2. Such differentiation can help us with the right utilization of species in biotechnical measures according to the site conditions. 
Table 2: Species occurence in altitudinal vegetation zones

\begin{tabular}{|c|c|c|c|c|}
\hline Disturbed & undisturbed & I. AVZ & II. AVZ & III. AVZ \\
\hline \multicolumn{5}{|l|}{ Acacia edgeworthii } \\
\hline \multicolumn{5}{|l|}{ Blepharis spiculifolia } \\
\hline & Boswellia popoviana & & & \\
\hline Justicia rigida & Justicia rigida & & & \\
\hline \multicolumn{5}{|l|}{$\begin{array}{l}\text { Limonium } \\
\text { paulayanum }\end{array}$} \\
\hline \multicolumn{5}{|l|}{$\begin{array}{l}\text { Limonium } \\
\text { socotranum }\end{array}$} \\
\hline \multicolumn{5}{|c|}{ Tamarix nilotica } \\
\hline & Ziziphus spina christi & & & \\
\hline \multicolumn{5}{|l|}{\begin{tabular}{|l|} 
Zygophyllum \\
qatarense
\end{tabular}} \\
\hline disturbed & undisturbed & I. AVZ & II. AVZ & III. AVZ \\
\hline \multicolumn{5}{|l|}{ Capparis cartilaginea } \\
\hline Cissus subaphylla & Cissus subaphylla & & & \\
\hline \multirow{2}{*}{ Commiphora kua } & Commiphora kua & & & \\
\hline & Commiphora ornifolia & & & \\
\hline Croton socotranus & Croton socotranus & & & \\
\hline \multicolumn{5}{|l|}{ Euphorbia arbuscula } \\
\hline \multirow[t]{2}{*}{$\begin{array}{l}\text { Pulicaria } \\
\text { stephanocarpa }\end{array}$} & Pulicaria stephanocarpa & & & \\
\hline & Sterculia africana & & & \\
\hline \multirow[t]{3}{*}{ disturbed } & undisturbed & I. AVZ & II. AVZ & III. AVZ \\
\hline & $\begin{array}{l}\text { Adenium obesum } \\
\text { subsp.socotranum }\end{array}$ & & & \\
\hline & Boswellia elongata & & & \\
\hline \multirow[t]{2}{*}{ Euphorbia schimperi } & Euphorbia schimperi & & & \\
\hline & Placopoda virgata & & & \\
\hline \multicolumn{5}{|l|}{ Salsola spinescens } \\
\hline \multirow[t]{4}{*}{ disturbed } & undisturbed & I. AVZ & II. AVZ & III. AVZ \\
\hline & Asparagus africanus & & & \\
\hline & Ballochia sp. & & & \\
\hline & Boswellia dioscoridis & & & \\
\hline \multirow[t]{2}{*}{$\begin{array}{l}\text { Buxanthus } \\
\text { pedicellatus }\end{array}$} & Buxanthus pedicellatus & & & \\
\hline & Carphalea obovata & & & \\
\hline \multirow{7}{*}{\begin{tabular}{|l|} 
Cissus \\
hamaderohensis
\end{tabular}} & Cissus hamaderohensis & & & \\
\hline & Clerodendrum leucophloeum cf & & & \\
\hline & Cryptolepis intricata & & & \\
\hline & Flueggea virosa & & & \\
\hline & Hibiscus spp. & & & \\
\hline & Rhus thyrsiflora & & & \\
\hline & Ruellia insignis & & & \\
\hline Solanum incanum & Solanum incanum & & & \\
\hline \multirow[t]{3}{*}{ Trichocalyx obovatus } & & & & \\
\hline & Trichocalyx orbiculatus & & & \\
\hline & Zygocarpum coeruleum & & & \\
\hline
\end{tabular}




\begin{tabular}{|l|l|l|l|l|}
\hline disturbed & undisturbed & I. AVZ & II. AVZ & III. AVZ \\
\hline & Allophylus rubifolius & & \\
\hline & Boswellia amaero & & \\
\hline & Cocculus balfourii & & \\
\hline & Croton sulcifructus & & \\
\hline & Euphorbia socotrana & & \\
\hline & Dracaena cinnabari & & \\
\hline Euryops arabicus & Euryops arabicus & & \\
\hline & Leucas kischenensis & & \\
\hline & Punica protopunica & & \\
\hline disturbed & Undisturbed & I. AVZ & II. AVZ & III. AVZ \\
\hline & Commiphora socotrana & & \\
\hline Jatropha unicostata & Jatropha unicostata & & \\
\hline Lycium sokotranum & Lycium sokotranum & & \\
\hline & $\begin{array}{l}\text { Maerua angolensis subsp. } \\
\text { socotrana }\end{array}$ & & \\
\hline Phoenix dactylifera & & &
\end{tabular}

Fig. 7: CCA of the effect of elevation ( $p$-value $=0.002$, explained variability $5.9 \%$ ). Red discs: disturbed sites, green triangles: undisturbed sites.

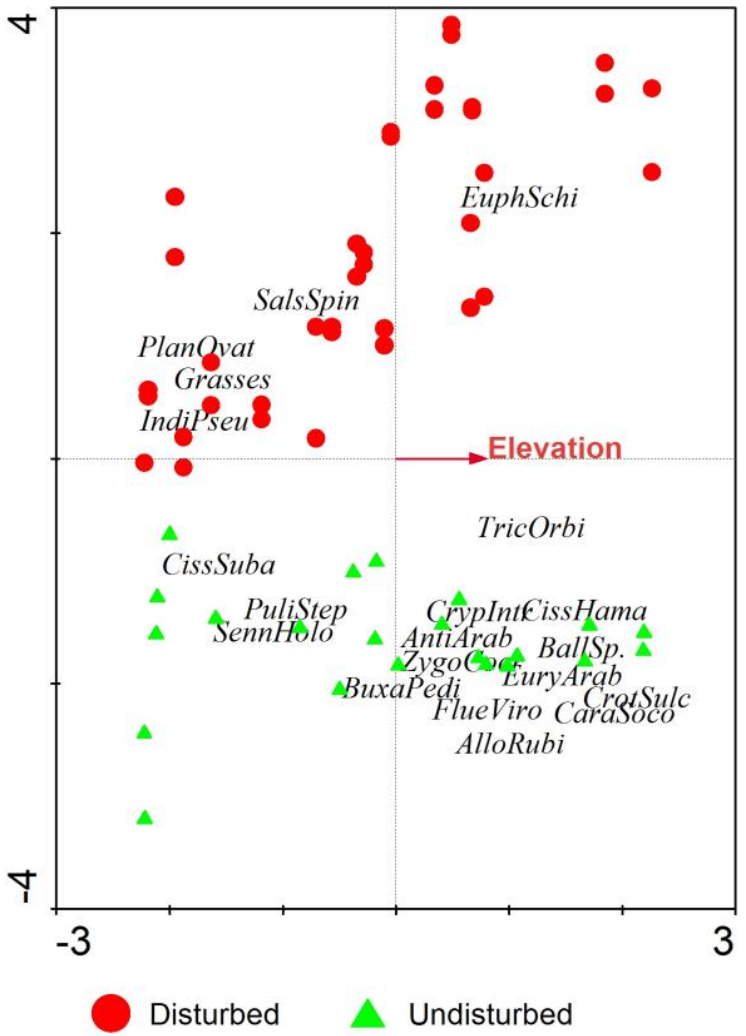




\section{Selection of recommended species for planting along roads}

According to the above mentioned results we can recommend potentially suitable composition of species for various site conditions and altitude. They are succesful in natural colonisation and ecological succession and therefore the presumption is that they will be useful in biotechnical measures. We selected only woody species (mainly trees and shrubs), especially species, which are able create more or less dense stands, prevent soil erosion with their roots and exhibit ornamental and others effects.

A. Sandy, saline soils in I.AVZ

Limonium socotranum, Limonium paulayanum, Zygophyllum qatarense, Acacia edgeworthii, Tamarix nilotica

B. Clayey soil in I. and II. AVZ

Pulicaria stephanocarpa, Justicia rigida, Cissus subaphylla, Croton socotranus, Euphorbia arbuscula, Commiphora kua, Jatropha unicostata, Lycium sokotranum

C. Rocky soil in I. and II. AVZ

Capparis cartilaginea, Commiphora kua, Boswellia popoviana

D. Sites of II and III. AVZ

Buxanthus pedicellatus, Cissus hamaderohensis, Trichocalyx obovatus, Jatropha unicostata, Lycium sokotranum

E. Sites of III. AVZ

Euryops arabicus, Buxanthus pedicellatus, Cissus hamaderohensis, Trichocalyx obovatus, Jatropha unicostata, Lycium sokotranum

\section{DiSCUSSION}

\section{Disturbance and impact of plant invasions}

Only a few alien plant species on the global scale seem to have the capacity to invade undisturbed native plant communities (Rejmanek, 1989). Climatic and edaphic comparability between the original and new habitats are necessary factors for the establishment of alien species (Holdgate, 1986). This is the reason why humid tropics of the Asia and Africa with shallow and highly leached soils are similar to Latin American home of such species represented e.g. by Ageratum conyzoides on the Soqotra islands. The most important factors determining introduced species richness were disturbance factors such as edge structure, intensity of mechanical disturbances, and distance to the nearest settlements (Arteaga et al., 2009). Senan et al. (2012) recorded a group of alien species, mostly woody plants, however e.g. Argemone mexicana and other herbs are also analyzed in their present and possible future distribution. Some other invasive herbaceous species were established they exhibit occurrence in our relevés both, in the initial (disturbed) and mature successional stages of vegetation (especially Solanum nigrum, Cleome viscosa, Ageratum conyzoides, Malva parvifolia). Their frequency of occurence along the road has not been too high (several relevés - moreover in both successional stages compared without significant differences - with the abundace scale $r-2$ ). However, their expansion phase could be expected after their latent period and it is crucial to know and reflect upon the 
biology and bionomy features of these species (e.g., Okunade, 2002; Holzmueller \& Jose, 2009; Kosaka et al., 2010).

\section{Alien plants in mountains and management concern}

The alien species that were most commonly recorded in mountains are likely to represent invasive plants of the accidental and utilitarian phases - and about three-quarters of the species recorded in mountains had no documented use or they may have been used for fodder, pasture, erosion control, food, timber or aesthetics (McDougall et al., 2011). In our list of invasive species on Soqotra we can find some examples of particular categories mentioned above, such as food (Phoenix dactylifera) and ornamental plant (Ageratum conyzoides), however, no invader is placed among those recommended for utilitarian prevention (Tab. 2), e.g. in the sense of erosion control. The reason why the variation between plots in lower altitudes is relatively small (Fig 5) could be higher degree of permanent disturbation in this elevation where any additional mechanical stress factors don't mean additional significant increase in the effect (e.g. Taylor et al., 2012).

The artifitial establishment of new vegetation cover in disturbed belt along the roads is possible by seeding the above mentioned shrubs (or herbaceous species). The seeds are necessary to be protect by mulching and antierosion nets (Theisen, 1992). The best time to carry out such measures is before the rain seson (Scholte \& de Geest, 2010). Newly planted tree saplings must be protected against grazing and in dry season irrigated for several years after planting.

\section{CONCLUSIONS}

(1) In all, 85 species were recorded on plots along the roads (21 species exhibit frequency higher than $10 \%$, the rest of the species pool is represented by scattered and rare plants).

(2) Disturbance associated with road construction has strong effect upon vegetation. (only small number of species is common for both, disturbed and undisturbed sites).

(3) Herbaceous species represent the most prevalent life form in vegetational stage of succession along the roads, shrubs and other life forms are present less frequently.

(4) The occurrence of the important segment of invaders was confirmed and relevant data on them were provided in previous publications from the Soqotra Island; list of alien species was extended, mainly in the herbaceous species group (e.g., Ageratum conyzoides, Solanum nigrum, Malva parviflora, etc.).

(5) Native species potentially successful in spontaneous vegetation succession along new roads were grouped according selected criteria and recommended to be planted there.

\section{ACKNOWLEDGEMENTS}

The article was published thanks to a support from the Ministry of Education of the Czech Republic (project LANDTEAM, reg. No. CZ.1.07/2.3.00/20.0004).

\section{REFERENCES}


Arévalo, J. R., Delgado, J. D., Otto, R., Naranjo, A., Salas, M., Fernandez-Palacios, J. D., (2005). Distribution of alien vs. native plant species in roadside communities along an altitudinal gradient in Tenerife and Gran Canaria (Canary Islands). Perspectives in Plant Ecology, Evolution and Systematics, 7: pp. 185-202.

Arteaga, M. A., Delgado, J.D., Otto, R., Fernandez-Palacios, J. M., Arévalo, J. R., (2009). How do alien plants distribute along roads on oceanic islands? A case study in Tenerife, Canary Islands. Biological Invasions, 11: pp. 1071-1086.

Braun-Blanquet, J., (1928). Pflanzensoziologie. Springer Verlag, Berlin.

Brown, G. et Mies, B.A., (2012). Vegetation ecology of Socotra. Plant and Vegetation 7. , Springers, $382 \mathrm{pp}$.

Bucek, A., Habrova, H., Kral, K., (2004). Geobiocenologická typologie ostrova Sokotry a jeji aplikace pri tvorbe ekologické site. Fyzickogeografický sborník 2. Masarykova univerzita v Brne.s. pp. 26-42.

Cheung, C. \& Devantier, L. (eds.) (2006). Socotra. A Natural History of the Islands and their Poeple. NHBS Environment Bookstore, UK: Odyssey Books \& Guides.

Crawley, M.J., (2007). The R book. John Wiley \& Sons Ltd., 942 pp.

Culek, M., Král, K., Habrová, H., Pavliš, J., Maděra, P., (2006). Socotra's Annual Weather Pattern. In Cheung, C., Devantier, L. (eds.): Socotra. A Natural History of the Islands and their People (pp. 200-205), NHBS Environment Bookstore, UK: Odyssey Books \& Guides

Daehler C. C., (2005). Upper-montane plant invasions in the Hawaiian Islands: Patterns and opportunities. Perspectives in Plant Ecology, Evolution and Systematics, 7: pp. 203-216.

De Sanctis M., Adeeb A., Farcomeni A., Patriarca Ch., Saed A., Attorre F., (2013). Classification and distribution patterns of plant communities on Socotra Island, Yemen. Applied Vegetation Science, 16: pp. 148-165.

Dogra K. S., Sood S. K., Dobhal P. K., Sharma S., (2010). Alien plant invasion and their impact on indigenous species diversity at global scale: A review. Journal of Ecology and the Natural Environment, 2(9), pp. 175-186.

Goosem M. W., Turton S. M., (2006). Roads and powerlines in the wet tropics World Heritage Area. Cooperative Research Centre for Tropical Rainforest Ecology and Management. Rainforest CRC, Cairns, Australia, 190 pp.

Habrová, H., (2004). Geobiocoenological differentiation as a tool for sustainable land-use of Socotra Island. Ekológia (Bratislava), Suppl. 1, 23: pp. 47-57.

Holdgate, M.W., (1986). Summary and Conclusions: Characteristics and Consequences of Biological Invasions. Philosophical Transactions of the Royle Society, London.

Hollander, M., Wolfe, D. A., (1999). Nonparametric Statistical Methods. New York: John Wiley \& Sons., 816 pp.

Holzmueller, E. J., José, S., (2009). Invasive plant conundrum: What makes the aliens so successful? Review/synthesis. Journal of Tropical Agriculture, 47(1-2): pp. 18-29.

Kilian, N., Hein, P., (2006). New and noteworthy records for the vascular plant flora of Socotra Island, Yemen. Englera, 28: pp. 57-78.

Klackenberg, J., (1985). The genus Exacum. Opera Bot., 84: pp. 5 - 144.

Kosaka, Y., Saikia, B., Mingki, T., Tag, H., Riba, T., Ando, K., (2010). Roadside distribution patterns of invasive alien plants along an altitudinal gradient in Arunachal Himalaya, India. Retrieved Juny 8, 2013, from BioOne (http://www.bioone.org/doi/full /10.1659/MRD-JOURNAL-D-10-00036.1). 
Kürschner, H., Hein, P., Kilian, N., Hubaishan, M. A., (2006). Diversity and zonation of the forests and woodlands of the mountains of northern Socotra, Yemen. Englera 28: pp. 11-55.

Magallón, S., Crane, P. R., Herendeen, P. S., (1999). Phylogenetic pattern, diversity and diversification of eudicots. Ann. Missouri Bot. Gard., 86: pp. 297 - 372.

McDougall, K. L., Alexander, J. M., Haider, S., Pauchard ,A., Walsh, N. G., Kueffer, C., (2011). Alien flora of mountains: global comparisons for the development of local preventive measures against plant invasions. Diversity Distrib., 17: pp. 103-111.

Miller, A. G., Morris, M., (2004). Ethnoflora of the Soqotra archipelago. The Royal Botanic Garden Edinburgh.

Okunade, A. L., (2002). Ageratum conyzoides L. Asteraceae. Review. Fitoterapia,73: 1-16.

Pauchard, A., Kueffer, C., Dietz, H., Daehler, C. C., Alexander, J., Edwards, P. J., Arévalo, J. R., Lohengrin, A Cavieres, L. A., Guisan, A., Haider, S., Jakobs, G., McDougall, K., Millar, C. I., Naylor, B. J., Parks, C. G., Rew, L. J., Seipel, T., (2009). Ain’t no mountain high enough: plant invasions reaching new elevations. Front Ecol Environ, 7(9): pp. 479-486.

Rejmanek, M., (1989). Invasibility of plant communities. Biological Invasions: A Global Perspective. In: Drake, J. A., Mooney, H.A., di Castri, F., Groves, R.H., Kruger, F.J., Rejmanek, M., Williamson, M., (Eds.), Wiley and Sons, (pp. 369-388), Chichester, England,

Scholte, P., (2007). Roads in Yemen's Protected Areas. Presentation to EU ambassadors Sana'a. Retrieved August 8, 2009 from Http://www.johnfarrar.plus.com/Roads\%20on\% 20Socotra\%20and\%20Yemen.pdf.

Scholte, P. \& de Geest, P., (2010). The climate of Socotra Island (Yemen): a first-time assessment of the timing of the monsoon wind reversal and its influence on precipitation patterns and vegetation. Journal of Arid Environments, 74, pp. 1507-1515.

Scholte, P., Al-Okaishi, A., Suleyman, A. S., (2011). When conservation precedes development: a case study of the opening up of the Socotra archipelago, Yemen. Fauna \& Flora International, Oryx, 45(3): 401-410.

Senan, A.S., Tomasetto, F., Farcomeni. A., Somashekar, R.K., Attorre, F., (2012). Determinants of plant species invasions in an arid island: evidence from Socotra Island (Yemen). Plant Ecol., 213: pp. 1381-1392.

Takhtajan, A., (1986). Floristic regions of the world. University of California Press.

Taylor, K., Brummer, T., Taper, M. L., Wing, A., Rew, L. J., (2012). Human-mediated long-distance dispersal: an empirical evaluation of seed dispersal by vehicles. Diversity Distrib., 18: pp. 1-10.

ter Braak, C., Šmilauer, P., (2002). Canoco reference manual and Canodraw for Windows user's guide: software for canonical community ordination, version 4.5. Microcomputer power, Ithaca, NY, US.

Theisen, M.S., (1992). The role of geosynthetics in erosion and sediment control: An overview. Geotextiles and Geomembranes, 11 (4-6): pp. 535-550.

Young, K. R., León, B., (2007). Tree-line changes along the Andes: implications of spatial patterns and dynamics. Phil. Trans. R. Soc. B 28, 362 (1478): pp. 263-272. 